\title{
HYDROXYSAFFLOR YELLOW A REVERSE CHEMOTHERAPY RESISTANCE VIA JNK AND P38 MAPK SIGNAL PATHWAY IN OVARIAN CANCER CELLS
}

\author{
CHENYU JIN ${ }^{1}$, JIALE YING ${ }^{2}$, WEIJI YANG ${ }^{3}$, RUOJIA LIANG ${ }^{4} *$ \\ ${ }^{I}$ Department of Traditional Chinese Medicine, The Second Affiliated Hospital, Zhejiang University School of Medicine, \\ Hangzhou, 310009, China \\ ${ }^{2}$ The Second Clinical Medical College, Zhejiang Chinese Medical University, Hangzhou, 310053, China \\ ${ }^{3}$ College of Life Science, Zhejiang Chinese Medical University, Hangzhou, 310053, China \\ ${ }^{4}$ Department of Gynaecology, The First Affiliated Hospital, Zhejiang Chinese Medical University, Hangzhou, 310006, China
}

*corresponding author: zghzjcy@zju.edu.cn

Manuscript received: December 2018

\begin{abstract}
Cisplatin based combination chemotherapy has become a conventional treatment for ovarian cancer. However, the appearance of drug resistance during the ovarian cancer treatment is one of the main obstacles for improving the therapeutic perspective of ovarian cancer. The aim of this study was to confirm the hypothesis that Hydroxysafflor yellow A (HYSA) can reverse chemotherapy resistance in ovarian cancer cells. In vitro study on A2780/DDP ovarian cell line was used to monitor cell proliferation by cytotoxicity assay and real time cellular analysis associated with flow cytometry that intend to determine if HSYA enhance cisplatin sensitivity through apoptosis. In vivo experiments on mice was used to identify the HYSA effects on cisplatin sensitivity. The in vitro studies showed that MAPK signal pathways were suppressed in cisplatin resistant ovarian cells A2780/DDP. Also, HSYA enhanced cisplatin sensitivity in cisplatin resistant organisms, in vivo. Mechanistically, HYSA increase P-JNK and P-38 levels, but has no effect on P-ERK, indicating that HYSA enhanced cisplatin sensitivity via JNK and P38 MAPK signalling pathways.
\end{abstract}

\section{Rezumat}

Chimioterapia bazată pe combinații cu cispaltin a devenit un tratament convențional pentru cancerul ovarian. Cu toate acestea, prevalența rezistenței medicamentoase în timpul tratamentului cancerului ovarian este unul dintre principalele obstacole în calea îmbunătățirii perspectivelor terapeutice. Scopul acestui studiu a fost confirmarea ipotezei că safflomin $A$ (HYSA) poate inversa rezistența la chimioterapie în celulele cancerigene ovariene. Studiul in vitro asupra liniei celulare A2780/DDP a fost utilizat pentru a monitoriza proliferarea celulară prin analiza citotoxicității și analiza celulară în timp real asociată cu citometria în flux, pentru a determina dacă HYSA crește sensibilitatea la cisplatin. S-au realizat experimente in vivo, pe șoareci, pentru a identifica efectele HYSA asupra sensibilitătii la cisplatină. Studiile in vitro au arătat că semnalele celulare au fost suprimate în celulele ovariene A2780/DDP rezistente la cisplatină. De asemenea, HSYA a îmbunătățit in vivo sensibilitatea la cisplatină în organismele rezistente. HYSA a crescu nivelurile P-JNK și P-38, dar nu a avut niciun efect asupra P-ERK, indicând faptul că HYSA acționează prin intermediul căilor de semnalizare JNK și P38 MAPK.

Keywords: Hydroxysafflor yellow A; chemotherapy resistance; MAPK; ovarian cancer; A2780/DDP cell line

\section{Introduction}

Ovarian cancer is the most common gynaecologic cancer, having the highest mortality rate from the gynaecological tumours. Due to lack of a complete early diagnosis, about $70 \% \sim 80 \%$ cancer patients are diagnosed in the advanced stage. Cisplatin based combination chemotherapy has become a conventional treatment of ovarian cancer. Most ovarian cancer patients have high initial response to cisplatin. However, the appearance of drug resistance during the treatment of ovarian cancer has become the main obstacle in improving the therapeutic perspective of ovarian cancer. Studies have found that about $75 \%$ $80 \%$ of epithelial ovarian cancer began to respond to chemotherapy, but at least $80 \%$ of all patients end up with drug resistance $[1,2]$.

Non-repairable cisplatin-induced DNA damage leads to the activation of a multi-branched signalling cascade with proapoptotic outcomes. Starting with the technological development and modernization of daily living, people have been exposed to a growing number of toxins and other harmful substances, and this has led to an explosion of cancers. Activation of signalling pathways that initiate tumorigenic changes in the target cell may be triggered by some external factors such as bisphenol [3]. Genetic and epigenetic alterations in the components of this complex signalling network have been associated with variable levels of resistance to cisplatin [4]. In order to avoid this 
FARMACIA, 2019, Vol. 67, 2

resistance, new pharmaceutical nanotechnology forms have been tried for transport to the target of the cytostatics $[5,6]$. Studies suggest that proapoptotic signal transducers such as mitogen-activated protein kinases (MAPK) family may contribute to the cisplatinresistant phenotype [7, 8]. The MAPKs in mammals include extracellular signal-regulated kinase (ERK), c-Jun NH2-terminal kinase (JNK) and P38 MAPK. These enzymes are serine-threonine protein kinases that regulate various cellular activities including proliferation, differentiation, apoptosis or survival, inflammation, and innate immunity [9]. These findings lead to the development of compound targeted MAPK signal pathway to reverse drug resistance.

Cancer is not a modern disease, it has always existed, and people have fought against it with vegetal extracts, the only products existing at the time. Hydroxysafflor yellow A (HSYA) is a compound with a single chalcone glycoside structure, with the highest efficacy from water soluble pharmacological active compounds of safflower. HSYA showed antiinflammatory properties, antioxidant effects, cell survival modulation, apoptosis and inhibition of tumour angiogenesis [10]. However, little is known about the role of HSYA in anti-drug resistance in cancer treatment. This study indented to identify if HYSA can influence the cisplatin resistance and its mechanism of action in order to provide a solution for advanced ovarian cancer resistance.

\section{Materials and Methods}

\section{Materials}

\section{Cell cultures and reagents}

The antibodies against Erk1/2, P-Erk1/2, JNK, PJNK, P38, P-P38 and GAPDH (glyceraldehyde 3phosphate dehydrogenase) were purchased from Sigma Chemical (St. Louis, MO, USA). Hydroxysafflor yellow A (HSYA) was purchased from Jiangyin Tian Jiang Pharmaceutical Co. Ltd.(Jiangyin, China). The human ovarian cancer cell line resistant to cisplatin A2780/DDP and A2780 were purchased from Shanghai cell bank of Chinese Academy of Sciences (Zhejiang, China). Human A2780/DDP ovarian cancer cells were routinely cultivated in RPMI-1640 medium containing $10 \% \mathrm{FBS}$ and $2 \mu \mathrm{g} / \mathrm{mL}$ cisplatin, at $37^{\circ} \mathrm{C}$ with $5 \% \mathrm{CO}_{2}$. Cells were passaged at $80 \%$ confluency, using $1 \mathrm{mmol} / \mathrm{L}$ ethylene diamine tetra acetic acid (EDTA) - $0.025 \%$ trypsin for 3 - $5 \mathrm{~min}$, and subcultured at a ratio of 1:3 - 1:5. Cells at the logarithmic growth phase were collected for experiments.

Cytotoxicity assay

One day before treatment, A2780, A2780/DDP cells were plated at a density of 5000 cells per well in 96-well plates. The cells were treated with cisplatin and HSYA. After 24-hours treatment, the cell viability was determined using Cell Counting Kit-8 (CCK-8) according to the manufacturer's instructions (Dojindo,
Kumamoto, Japan). The cell survival rates were expressed as mean \pm S.D. from at least three independent experiments.

Real time cellular analysis (RTCA) for monitoring cell proliferation

First, A2780 and A2780/DDP cells at the logarithmic growth phase were obtained and the cell concentration was adjusted to $5 \times 10^{4} / \mathrm{mL}$. E-Plate 16 test board with $50 \mu \mathrm{L}$ medium was used to determine the background resistance value. Then, $100 \mu \mathrm{L}$ of the above-mentioned cell suspension was added into each well of E-Plate16. The E-Plate 16 was then placed on the RTCA station in the incubator, with cell index detected at intervals of $15 \mathrm{~min}$. In the second day, according to the experimental design, the $5 \mu \mathrm{L}$ working fluid was added to the cell wall along the whole wall. The cells were divided in 3 groups as follows: the first one was treated with cisplatin $(25 \mu \mathrm{g} / \mathrm{mL})$, the second one received HSYA $(1 \mathrm{mg} / \mathrm{mL})+$ cisplatin $(25 \mu \mathrm{g} / \mathrm{mL})$ and a control group. For each group the RTCA test was done every 1 minute for two hours to observe the shortterm effect of the drugs and then, every $15 \mathrm{~min}$ for a total of 72 hours to observe the long-term effect of the drug.

Evaluation of apoptosis by flow cytometry

For detection of apoptosis by FACS, A2780/DDP cells were treated with cisplatin $(25 \mu \mathrm{g} / \mathrm{mL})$ and HSYA $(1 \mathrm{mg} / \mathrm{mL})$ for 24 hours. Then the cells were collected for annexin V-phycoerythrin and 7-aminoactinomycin D (7-AAD) double staining. In short, the cells were washed with phosphate buffered saline (PBS) for three times and stained according to the manufacturer's instructions (Guava Nexin ${ }^{\circledR}$ Reagent kit, Millipore, USA). Samples were then analysed using Guava EasyCyte Plus (Millipore, USA) within 30 mins after the staining.

Animal experiment on nude mice model of transplanted tumour

Twenty female BALB/c nude mice, 4 weeks old were obtained from Shanghai Sippr-BK laboratory animal Co. Ltd. The animal care committee of Zhejiang Chinese Medical University approved the animal experiment and the code number of the animals was SCXK (HU) 2013-0016. All of the experimental nude mice were kept under specific pathogen-free (SPF) conditions in the Laboratory Animal Centre of Zhejiang at a relative humidity of $45 \%-60 \%$ and a temperature of $26 \pm 2{ }^{\circ} \mathrm{C}$. The code number of the laboratory animal center was SYXK (ZHE) 20140008. A2780/DDP cells concentration were adjusted to $5 \times 10^{7} / \mathrm{mL}$. Then $200 \mu \mathrm{L}$ of the above-mentioned cell suspension was injected subcutaneously into the right flank of each nude mouse. After two weeks, every nude mouse has grown a tumour at least a volume of approximately $60 \mathrm{~mm}^{3}$. Then, 20 nude mice were randomly divided into 4 experimental groups as follows: cisplatin group treated with 3 
$\mathrm{mg} / \mathrm{kg}$ body weight cisplatin, HYSA group treated with $1.1 \mathrm{~g} / \mathrm{kg}$ body weight HYSA, cisplatin plus HYSA group that received $3 \mathrm{mg} / \mathrm{kg}$ bw cisplatin and 1.1 $\mathrm{g} / \mathrm{kg}$ bw HYSA and the control group that received physiological saline solution. The treatment was done for each group once every three days for five weeks. Health status and tumour growth of mice in each group were checked daily, with an electronic digital calliper and weekly measurement of tumour size as well as tumour volume was calculated according to the formula:

$$
\text { tumour volume }\left(\mathrm{mm}^{3}\right) \mathrm{V}=\left(\mathrm{W}^{2} \times \mathrm{L}\right) / 2 \text {, }
$$

where, $\mathrm{W}$ is tumour width and $\mathrm{L}$ is tumour length. At the end of the experiment, the animals were euthanized and the organs were collected.

\section{Western blot analysis}

For biochemical analysis, cells and tissues were washed with ice cold PBS (Beyotime Institute of Biotechnology, Jiangsu, China) and lysed in radioimmunoprecipitation assay lysis buffer (50 mM Tris, pH 7.4; 150 mM NaCl; $1 \%$ Triton X100; $1 \%$ sodium deoxycholate; $0.1 \%$ sodium dodecyl sulphate (SDS); Beyotime Institute of Biotechnology). The lysates were kept in ice for $30 \mathrm{mins}$ and clarified by centrifugation at $12,000 \mathrm{x}$ g for $25 \mathrm{mins}$ at $4^{\circ} \mathrm{C}$. The clarified lysate was then collected and the Erk1/2, P-Erk1/2, JNK, P-JNK, P38, P-38 and GAPDH proteins were separated by $12 \%$ SD Spolyacrylamide gel electrophoresis (30100 $\mu$ g protein/lane) which was later transferred to a polyvinylidine fluoride membrane (all from Beyotime Institute of Biotechnology). After the transfer, the membranes were incubated in $5 \%$ milk for an hour and then with antibodies diluted in fat-free milk. The membranes were then washed with Tris buffered saline and Tween 20 (Beyotime Institute of Biotechnology) and incubated with the HRP (horseradish peroxidase) conjugated secondary antibodies. Immunoreactive proteins were visualized using a BeyoECL Plus kit (Beyotime Institute of Biotechnology).

Statistical analysis

Statistical analysis was conducted using SPSS, version 18.0 (SPSS, Inc., Chicago, IL, USA). Each experiment was performed at least 3 times. Data were indicated as mean values \pm standard deviation and differences were evaluated using Student's t-test. A probability value $<0.05$ was considered statistically significant.

\section{Results and Discussion}

HSYA enhanced cisplatin sensitivity in cisplatin resistant cells

First, we confirmed the cisplatin resistance character of A2780/DDP cells. As shown in Figure 1A, the survival of A2780/DDP cells is increased in cisplatin treatment compared with A2780 cells. After the treatment with $50 \mu \mathrm{g} / \mathrm{mL}$ cisplatin the viability of since the cell viability of A2780/DPP cells was $63 \%$ compared with only $19 \%$ viability for A2780 cells. Then, we investigated the potential role of HSYA in A2780/DDP cells. These cells were treated with cisplatin $(25 \mu \mathrm{g} / \mathrm{mL})$ alone or combined with HYSA $(1 \mathrm{mg} / \mathrm{mL})$. As a result, the viability of A2780/DDP cells was significantly decreased by HYSA and cisplatincombined treatment (Figure 1B). After 12 hours of treatment the A2780/DDP cell viability in cisplatin + HSYA group was $89 \%$ compared with $94 \%$ in cisplatin group and after 60 hours of treatment the A2780/DDP cell viability was only $23 \%$ compared with $58 \%$ in cisplatin group. RTCA analysis showed that although the proliferation of A2780/DDP cells was inhibited by cisplatin treatment, the cells still survived (Figure 1C). In contrast, HYSA and cisplatin combined treatment led to significant cell death (Figure 1C). These results suggested that HSYA enhanced cisplatin-sensitivity in cisplatin resistant cells.

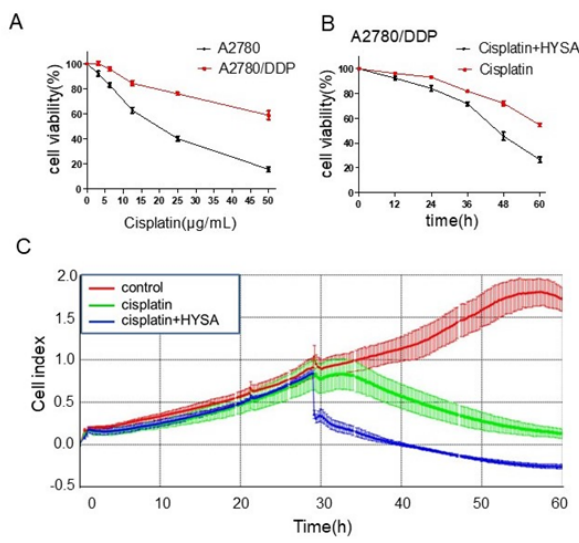

Figure 1.

HSYA enhanced cisplatin sensitivity in cisplatin resistant cells. (A) The viability of A2780 and A2780/DDP cells treated with cisplatin. (B) The viability of A2780/DDP cells treated with cisplatin and HYSA. (C) Cell proliferation of A2780/DDP cells treated with cisplatin and HYSA

HSYA enhanced cisplatin sensitivity through apoptosis Apoptosis was the major cell death type induced by cisplatin. To determine whether HSYA enhanced cisplatin induced apoptosis in A2780/DDP cells, the cells were treated with cisplatin $(25 \mu \mathrm{g} / \mathrm{mL})$ alone or combined with HYSA $(1 \mathrm{mg} / \mathrm{mL})$ for 24 hours (Figure 2A and 2B). The proportion of AV(Annexin$\mathrm{V})+/$ PI (propidium iodide) + (late stage of apoptosis) was increased from $0.09 \%$ in control group cells to $6.33 \%$ of the cisplatin group, and to $15.66 \%$ of the cisplatin + HSYA group. The number of AV+/PI- (early stage of apoptosis) increased from $0.36 \%$ to $9.36 \%$. These results suggested that HSYA enhanced cisplatin sensitivity through induced apoptosis. 
A
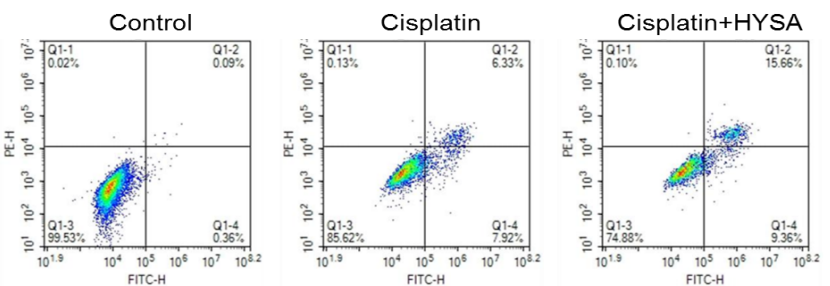

B

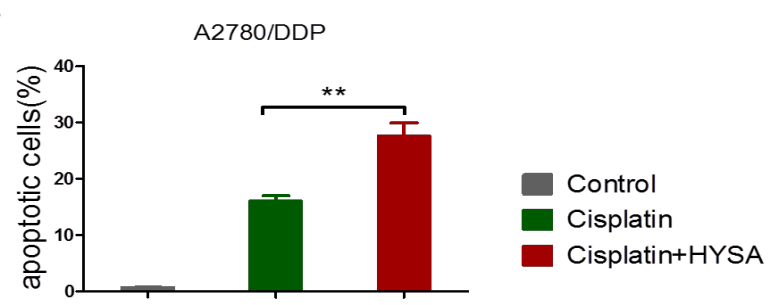

Figure 2.

HSYA enhanced cisplatin sensitivity through apoptosis. (A) Apoptosis of A2780/DDP cells treated with cisplatin and HYSA was determined by flow cytometry. (B) Graphic apoptotic rate of A2780/DDP cells

HYSA enhanced cisplatin sensitivity in vivo

We employed the xenograft model to investigate the in vivo role of HYSA in cisplatin resistance. After 5 weeks treatment, the HYSA group showed a decrease of the tumour volume, followed by the cisplatin group and then cisplatin + HYSA with the smallest tumour volume (Figure 3A and 3B). The tumour tissues were analysed by HE staining and the results showed that there were more apoptotic cells in cisplatin combined with HSYA group compared with the cisplatin group (Figure 3C and 3D). The average tumour volumes of the control, HSYA, cisplatin and cisplatin+ HSYA groups were $1984.29,1566.81,1104.23$ and respectively $695.48 \mathrm{~mm}^{3}$. The average tumour weights of the control, HSYA, cisplatin and cisplatin+ HSYA groups were $4.71,4.54,3.53$ and respectively $2.76 \mathrm{~g}$.

These results demonstrated that HSYA enhanced cisplatin sensitivity in vivo.
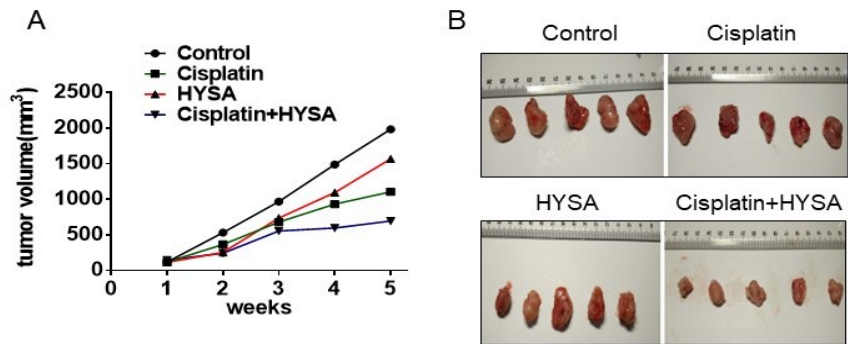

C

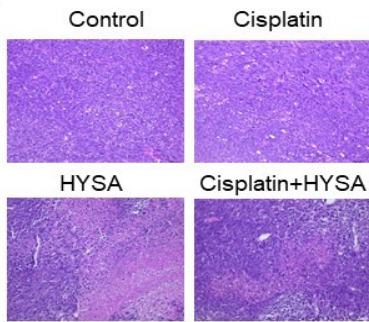

Figure 3.

HYSA enhanced cisplatin sensitivity in vivo. (A) The growth of tumour treated with cisplatin and HYSA. (B) The tumours after 5 weeks by cisplatin and HYSA treatment. (C) HE staining of the tumours

HYSA enhanced cisplatin sensitivity via JNK and P38 MAPK signal pathways

Apoptosis maybe controlled by various signal pathways, including MAPK signal pathways [10-13].
ERK, JNK, P38 are three sub-pathways of MAPK. We found that the levels of P-ERK, P-JNK, P-P38 were down regulated in A2780/DDP cells compared with A2780 cells (Figure 4A), indicating 
that MAPK signal pathways were suppressed in cisplatin resistant cells. When A2780/DDP cells were treated with HYSA, P-JNK and P-38 levels but not P-ERK were significantly activated (Figure
4B) compared with GAPDH, indicating that HYSA enhanced cisplatin sensitivity via JNK and P38 MAPK signalling pathways.

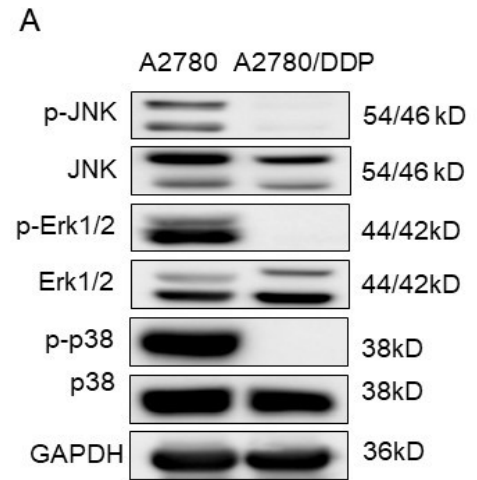

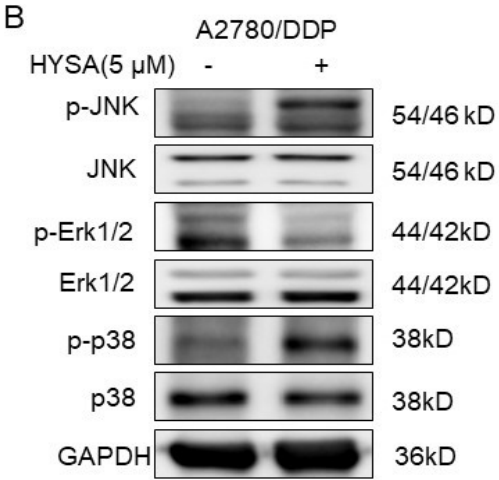

Figure 4.

HYSA enhanced cisplatin sensitivity via JNK and P38 MAPK signalling pathways. (A) The expression of pErk1/2, Erk1/2, p-JNK, JNK, p-p38, p38 and GAPDH in A2780 and A2780/DDP cells (B) The expression of pErk1/2, Erk1/2, p-JNK, JNK, p-p38, p38 and GAPDH in A2780/DDP cells after HYSA treatment

Ovarian cancer is the most malignant tumour in gynaecological tumours, and cisplatin is widely used as a basic drug for ovarian cancer chemotherapy. In patients with advanced ovarian cancer, the rate of recurrence was $70 \%$ after chemotherapy, and the rate of chemotherapy resistance was $70 \%$, which directly affects the 5 years survival rate of advanced ovarian cancer patients [14]. Classical chemotherapy produces severe side effects, of which severe immunosuppression favours severe bacterial infections with treatment resistant germs such as Staphylococcus aureus [15, 16, 17] or fungus from Aspergillus, Fusarium [18]. Therefore, screening resistant reversal drugs from traditional Chinese medicine and developing a specific resistance reversal agent will help to improve the 5 years survival rate of advanced ovarian cancer patients. This process is triggered by autocrine and paracrine signals. Thus, agents that may block or reverse this process may offer a promising therapeutic strategy to limit cancer diffusion.

In the current study, cytotoxicity assay and real time cellular analysis used to monitor cell proliferation showed that HSYA enhanced cisplatin sensitivity in cisplatin resistant cells. Flow cytometry suggested that HSYA enhanced cisplatin sensitivity through apoptosis. Animal experiments showed that HYSA enhanced cisplatin sensitivity in vivo. HSYA blocks the expression of apoptosis markers in the Western blotting assays. We further showed that HSYA can enhance cisplatin sensitivity via JNK and P38 MAPK, which is associated with apoptosis. These results provide new mechanistic bases for the therapeutic application of HSYA in the patients with ovarian cancer.

\section{Conclusions}

HSYA, has shown to have anti-apoptotic, inflammatory effects, antioxidant, cell survival modulating potential and it inhibits the tumour angiogenesis. Most importantly, to the best of our knowledge, our study is the first to demonstrate that the anti-apoptotic effect of HSYA was associated with reverse chemotherapy resistance in cultured ovarian cancer cells. Our results offer a new perspective on the role of HSYA in preventing the progression of ovarian cancer.

\section{Acknowledgement}

This research was supported by Zhejiang Provincial Natural Science Foundation of China under Grant No.Y15H270031.

\section{References}

1. Coleman RL, Monk BJ, Sood AK, Herzog TJ, Latest research and treatment of advanced-stage epithelial ovarian cancer. Nat Rev Clin Oncol., 2013; 10: 211-224.

2. Leitao MM Jr, Chi DS, Surgical management of recurrent ovarian cancer. Semin Oncol., 2009; 36: 106-111.

3. Jalal N, Surendranath AR, Pathak JL, Yu S, Chung $\mathrm{CY}$, Bisphenol A (BPA) the mighty and the mutagenic. Toxicol Rep., 2018; 5: 76-84.

4. Galluzzi L, Senovilla L, Vitale I, Michels J, Martins I, Kepp O, Castedo M, Kroemer G, Molecular mechanisms of cisplatin resistance. Oncogene, 2012; 31:1869-1883.

5. Kadry MO, Abdel-Megeed RM, El-Meliegy E, AbdelHamid AZ, Crosstalk between GSK-3, c-Fos, NFкB and TNF- $\alpha$ signaling pathways play an ambitious role in Chitosan Nanoparticles Cancer Therapy. Toxicol Rep., 2018; 5: 723-727. 
6. Danciu C, Pinzaru IA, Dehelean CA, Hancianu M, Zupko I, Navolan D, Licker M, Ghiulai RM, Şoica $\mathrm{CM}$, Antiproliferative and antimicrobial properties of pure and encapsulated rutin. Farmacia, 2018; 66(2): 302-308.

7. Mansouri A, Ridgway LD, Korapati AL, Zhang Q, Tian L, Wang Y, Siddik ZH, Mills GB, Claret FX, Sustained activation of JNK/p38 MAPK pathways in response to cisplatin leads to Fas ligand induction and cell death in ovarian carcinoma cells. J Biol Chem.,2003; 278: 19245-19256.

8. Brozovic A, Osmak M, Activation of mitogenactivated protein kinases by cisplatin and their role in cisplatin-resistance. Cancer Lett., 2007; 251: 1-16.

9. Kim EK, Choi EJ, Compromised MAPK signaling in human diseases: an update. Arch Toxicol., 2015; 89:867-82.

10. Yang F, Li J, Zhu J, Wang D, Chen S, Bai X, Hydroxysafflor yellow A inhibits angiogenesis of hepatocellular carcinoma via blocking ERK/MAPK and NF- $\mathrm{KB}$ signaling pathway in $\mathrm{H} 22$ tumor-bearing mice. Eur J Pharmacol., 2015; 754: 105-114.

11. Sui X, Kong N, Ye L, Han W, Zhou J, Zhang Q, He C, Pan H, p38 and JNK MAPK pathways control the balance of apoptosis and autophagy in response to chemotherapeutic agents. Cancer Lett., 2014; 344: 174-179.

12. Mehedintu C, Antonovici M, Brinduse L, Bratila E, Stanculescu R, Berceanu C, Bratu O, Pituru S, Onofriescu M, Matasariu DR, The influence of progesterone on immunohystochemical markers in endometriosis. Rev Chim (Bucharest), 2018; 69(3): 581-584.

13. Li Q, Chen M, Liu H, Yang L, Yang T, He G, The dual role of ERK signaling in the apoptosis of neurons. Front Biosci (Landmark Ed), 2014; 19: 1411-1417.

14. Pectasides D, Farmakis D, Koumarianou A, The role of neoadjuvant chemotherapy in the treatment of advanced ovarian cancer. Oncology, 2005; 68(1): 64-70.

15. Zlatian O, Balasoiu AT, Balasoiu M, Cristea O., Docea AO, Mitrut R, Spandidos DA, Tsatsakis AM, Bancescu G, Calina D, Antimicrobial resistance in bacterial pathogens among hospitalised patients with severe invasive infections. Exp Ther Med., 2018; 16: 4499-4510

16. Ungureanu A, Zlatian O, Mitroi G, Drocaş A, Ţîrcă T, Călina D, Dehelean C, Docea AO, Izotov BN, Rakitskii V, Cioboată R, Spandidos DA, Tsatsakis AM, Găman A, Staphylococcus aureus colonisation in patients from a primary regional hospital. $\mathrm{Mol} \mathrm{Med}$ Rep., 2017; 16: 8771-8780.

17. Georgescu M, Tăpăloagă PR, Tăpăloagă D, Furnaris F, Ginghină O, Negrei C, Giuglea C, Bălălău C, Ștefănescu E, Popescu IA, Georgescu D, Evaluation of antimicrobial potential of nigella sativa oil in a model food matrix. Farmacia, 2018; 66(6): 1028-1036.

18. Tănase A, Coliță A, Ianoşi G, Neagoe D, Brănişteanu DE, Călina D, Docea AO, Tsatsakis A, Ianoşi SL, Rare case of disseminated fusariosis in a young patient with graft $v s$. host disease following an allogeneic transplant. Exp Ther Med., 2016; 12: 2078-2082. 